\title{
A technique for reproduction of Varroa jacobsoni Oud under laboratory conditions
}

\author{
F Nazzi, N Milani \\ Dipartimento di Biologia Applicata alla Difesa delle Piante, Università di Udine, \\ via delle Scienze, 208, 33100 Udine, Italy
}

(Received 10 February 1994; accepted 6 July 1994)

\begin{abstract}
Summary - Varroa jacobsoni females were taken from bee larvae within $0-15 \mathrm{~h}$ of capping and transferred to larvae of the same age in artificial cells, $5.8-7.0 \mathrm{~mm}$ in diameter, made of beeswax or gelatin. The percentage of fertile Varroa females in gelatin cells was at least 3 times higher than in beeswax cells of similar diameter. The proportion of reproducing females was higher for both materials in narrower cells. In 6.0-mm gelatin cells the average proportion of reproducing females was $62 \%$ and the number of offspring per reproducing female 3.5. About 1 adult daughter per 2 starting Varroa mothers was obtained.
\end{abstract}

in vitro reproduction / Varroa jacobsoni

\section{INTRODUCTION}

Much effort has been made to gain more knowledge on the biology of Varroa jacobsoni Oudemans, but the study of important aspects of the life cycle of the mite, like feeding, mating and oviposition, is made difficult by the fact that they take place inside a sealed cell in the bee hive. Many attempts have been made so far to rear the Varroa mite on its host under laboratory conditions (Avdeeva, 1978, 1979; Sakai et al, 1979; Issa and Gonçalves, 1985; Accorti and Nannelli, 1988; Chiesa and Milani, 1988; Abbas and Engels, 1989; Chiesa et al, 1989; Beetsma and Zonnenveld, 1992). While a satisfactory survival rate of the mite was achieved, the percentage of fertile females was much lower than that observed under natural conditions. Donzé (1989) obtained reproduction under laboratory conditions, but he used cells that had been kept in the hive until the sealing of the cells.

Varroa females taken from larvae capped 0-15 h earlier do not lay eggs when transferred to an unsuitable environment. The percentage of reproducing mites is strongly influenced by the environment. In particular, factors inducing reproduction seem to be present in natural cells in which a bee larva has developed (Milani and Chiesa, 1990). For this reason, cells made of various materials have been tested to get the mite to reproduce under laboratory conditions. In 
this study, experiments carried out with gelatin cells are described, and data on the reproduction of the mite under these conditions are reported.

\section{MATERIALS AND METHODS}

\section{Cells}

Gelatin cells for electron microscopy (Agar Scientific Ltd, Cambridge, UK), sizes 0, 1 and 2 (inner diameter about $7.0,6.5$ and $6.0 \mathrm{~mm}$, respectively) were used. The cap of the cells was pierced 3 or 4 times using a No 2 insect pin to make gas exchange with the exterior possible.

Artificial beeswax cells 5.8 and $6.8 \mathrm{~mm}$ inner diameter were capped with a small piece of filter paper (Milani and Chiesa, 1990).

\section{Bee larvae and Varroa females}

Although the fertility of Varroa is higher on drone larvae than on worker larvae, the latter were chosen as they are available for a longer period of the year.

The study was carried out on bees from Friuli (northeastern Italy), an area of racial hybridization between Apis mellifera carnica Pollman and $A m$ ligustica Spinola. Worker bee larvae and adult females of $V$ jacobsoni were taken from cells that had been capped $0-15 \mathrm{~h}$ earlier according to the technique described by Chiesa et al (1989).

One bee larva and 1 Varroa female were inserted into each cell. The cells were placed in a Petri dish in a horizontal position and kept in an incubator at $34.5^{\circ} \mathrm{C}$ and $75 \% \mathrm{RH}$.

After $12 \mathrm{~d}$ the cells were opened and inspected under a dissecting microscope to note whether the bee and the Varroa female were alive and to ascertain the presence, number and developmental stage of offspring.

\section{Experiments}

Three series of experiments were carried out.

1) The fertility of Varroa females in gelatin and beeswax cells was compared; cells of 2 differ- ent sizes $(6.0$ and 7.0 , and 5.8 and $6.8 \mathrm{~mm}$ diameter, respectively) were used. The experiment was carried out on different dates using small batches of cells of equal size for each experimental group. In total 60 cells were used per experimental group.

To ascertain possible variations of cell dimensions occurring during the rearing, the volume of 10 cells previously used for the rearing and that of new cells were compared by weighing the amount of decane needed to fill them.

2) The fertility of Varroa females in gelatin cells of 3 different sizes $(0,1$ and 2$)$ was compared. Thirty cells of each size were used.

3) Varroa females were placed in gelatin cells size 2; the experiment was replicated 4 times. A total of 136 cells was prepared.

\section{Statistical analysis}

The proportion of reproducing female mites in different experimental groups were compared using the exact Fisher test (Fisher, 1970). The mites placed on larvae that died during the experiments were not included in the comparisons.

\section{RESULTS AND DISCUSSION}

\section{Beeswax and gelatin cells}

The percentage of reproducing Varroa females was higher in the gelatin cells than in wax cells of similar diameter, the differences between the 2 materials being significant $(P<0.01)$ for both diameters. The progeny per reproducing female was about the same in cells of different sizes and materials (table I). Many bee larvae reared in narrower cells died due to injuries caused during insertion into the cell. During the rearing cycle a reduction in the diameter and sometimes a slight, irregular deformation of the gelatin cells were observed. The mean reduction in the volume was $16 \%$ (corresponding to an $8 \%$ reduction in the diameter). 
Table I. Number of surviving and reproducing Varroa females in gelatin and beeswax cells of different diameter *.

\begin{tabular}{|c|c|c|c|c|}
\hline type & $\begin{array}{c}\text { Surviving } \\
\text { bee larvae }\end{array}$ & $\begin{array}{c}\text { Surviving } \\
\text { Varroa females }\end{array}$ & $\begin{array}{l}\text { Reproducing } \\
\text { Varroa females }\end{array}$ & $\begin{array}{c}\text { Offspring per } \\
\text { fertile male } \pm \text { sd }\end{array}$ \\
\hline
\end{tabular}

$\begin{array}{lllll}\text { Gelatin } 6.0 \mathrm{~mm} & 25 & 19 & 11^{\mathrm{A}} & 4.2 \pm 0.98 \\ \text { Gelatin } 7.0 \mathrm{~mm} & 52 & 50 & 12^{\mathrm{B}} & 2.1 \pm 1.00 \\ \text { Wax } 5.8 \mathrm{~mm} & 34 & 31 & 6^{\mathrm{BC}} & 2.8 \pm 1.72 \\ \text { Wax } 6.8 \mathrm{~mm} & 43 & 42 & 2^{\mathrm{C}} & 3.0 \pm 2.83\end{array}$
${ }^{*}$ Groups for which the ratio of reproducing to surviving mites differs significantly $(P<0.01)$ are labelled with different
capital letters.

The factors responsible for the high percentage of reproducing Varroa females in gelatin cells are still not completely understood; the reduction of the cell size may play a role, but is unlikely to entirely account for it since the fertility is rather higher in $7.0 \mathrm{~mm}$ gelatin cells than in $5.8 \mathrm{~mm}$ beeswax cells.

\section{Size of the gelatin cells}

Seventy-one percent of the Varroa females placed in the $6.0-\mathrm{mm}$ cells laid eggs, while only 31 and $14 \%$ of those placed in cells 6.5 and $7.0 \mathrm{~mm}$, respectively, did. The proportion of fertile Varroa mites was significantly higher in $6.0-\mathrm{mm}$ cells than in the larger ones (table II). The offspring per reproducing female was almost the same in cells of different sizes.

The increase in the percentage of reproducing mites in narrower cells confirms the findings of Milani and Chiesa (1990) concerning wax cells. The use of cells smaller than size 2 is not advisable because of the difficulties in inserting a bee larva without harming it.

\section{Reproduction of Varroa females in gelatin cells}

Only 8 out of the 106 Varroa females placed on larvae that were still alive at the end of the experiments died. Sixty-two percent of the mites laid eggs and the average number of eggs per fertile female was 3.5 (table III).

Table II. Number of surviving and reproducing Varroa females in gelatin cells of different diameter *.

$\begin{array}{lrccc}\begin{array}{l}\text { Cell diameter } \\ (\mathrm{mm})\end{array} & \begin{array}{c}\text { Surviving } \\ \text { bee larvae }\end{array} & \begin{array}{c}\text { Surviving } \\ \text { Varroa females }\end{array} & \begin{array}{c}\text { Reproducing } \\ \text { Varroa females }\end{array} & \begin{array}{c}\text { Offspring per } \\ \text { fertile female } \pm \text { sd }\end{array}\end{array}$

\begin{tabular}{rrrrr}
\hline 6.0 & 19 & 17 & $12^{\mathrm{a}}$ & $3.5 \pm 1.73$ \\
6.5 & 29 & 26 & $8^{\mathrm{b}}$ & $2.4 \pm 1.85$ \\
7.0 & 25 & 22 & $3^{\mathrm{b}}$ & $3 \pm 1.73$
\end{tabular}

\footnotetext{
* Groups for which the ratio of reproducing to surviving mites differs significantly $(P<0.05)$ are labelled with different letters.
} 
Table III. Number of surviving and reproducing Varroa females in 6.0-mm diameter gelatin cells.

$\begin{array}{lcccc}\text { Replication } & \begin{array}{c}\text { Surviving } \\ \text { bee larvae }\end{array} & \begin{array}{c}\text { Surviving } \\ \text { Varroa females }\end{array} & \begin{array}{c}\text { Reproducing } \\ \text { Varroa females }\end{array} & \begin{array}{c}\text { Offspring per } \\ \text { fertile female }\end{array} \\ \text { I } & 19 & 17 & 12 & 3.5 \\ \text { II } & 28 & 26 & 15 & 4.1 \\ \text { III } & 40 & 39 & 24 & 3.0 \\ \text { IV } & 19 & 16 & 10 & 3.9 \\ \text { Total } & 106 & 98 & 61 & 3.5\end{array}$

Seventy percent of the reproducing females laid 3 or more eggs.

The mean composition of the progeny was as follows: eggs $12.8 \%$; protonymphs $25.1 \%$; female deutonymphs $22.2 \%$; adult females $27.1 \%$; adult males $12.81 \%$ (the protonymphs were not sexed). Fifty-two live adult daughters were obtained out of 106 starting Varroa mothers. The fertility is not far from that observed under natural conditions (84\% according to Schulz, 1984) and is higher than that obtained in artificial cells even on drone larvae using Varroa females taken from brood $24 \mathrm{~h}$ after capping (Abbas and Engels, 1898). These results appear promising in view of establishing a rearing technique for the mite under laboratory conditions once the reproduction of the daughters has been achieved.

\section{CONCLUSIONS}

The results confirm the importance of the rearing environment for the reproduction of Varroa although they do not give an explanation for the increased proportion of fertile females in gelatin cells. At present, gelatin cells appear to be the best rearing environment tested to obtain reproduction of $V$ jacobsoni females and the first obstacle to the rearing of the mite under laboratory conditions (ie the poor reproduction of the mite in artificial cells) has been overcome. An additional advantage is the transparency of gelatin cells which will make it possible to directly observe the behaviour of the mite inside the cell.

\section{ACKNOWLEDGMENTS}

We wish to thank M D'Agaro for technical assistance and $\mathrm{J}$ Rogers for the revision of the English text. This research was supported by a grant from the MURST $(60 \%)$, USU, research project "Semiochimici di artropodi di interesse agrario".

\section{Résumé - Technique pour obtenir la reproduction de Varroa jacobsoni Oud} en conditions de laboratoire. Des expériences précédentes laissent penser que le milieu d'élevage joue un rôle important dans la reproduction de l'acarien parasite Varroa jacobsoni Oud. Différents types de cellules artificielles ont été jusqu'à présent testés pour vérifier s'ils convenaient à l'élevage de l'acarien dans des conditions de laboratoire, mais le pourcentage de femelles fertiles était beaucoup plus bas que celui observé en conditions naturelles. Nous rendons compte ici d'expériences faites avec des cellules en gélatine. Des varroas femelles ont été prélevés sur des larves d'abeilles entre 0 et $15 \mathrm{~h}$ après l'operculation et transférés sur des larves de même âge dans des cellules artificielles ; l'élevage a été réalisé en étuve à $34,5^{\circ} \mathrm{C}$ et $75 \%$ d'humi- 
dité relative. Les cellules ont été ouvertes $12 \mathrm{j}$ plus tard et inspectées sous une loupe binoculaire. La mortalité, la fertilité et la descendance des varroas femelles ont été notées. On a comparé des cellules artificielles en cire d'abeille et des cellules en gélatine de divers diamètres $(5,8$ à $7,0 \mathrm{~mm})$. Pour un même diamètre le pourcentage de varroas femelles fertiles a été beaucoup plus élevé dans les cellules en gélatine que dans celles en cire (tableau I), atteignant $71 \%$ dans les cellules de $6,0 \mathrm{~mm}$ de diamètre (tableau II). Le pourcentage de femelles reproductrices a été plus élevé dans les cellules étroites pour les 2 types de matériau (tableaux I et II). II a été en moyenne de 62\% dans les cellules en gélatine de $6,0 \mathrm{~mm}$ et le nombre de descendants a été de 3,5 par femelle reproductrice (tableau III). Les résultats confirment l'importance du milieu d'élevage pour la reproduction de l'acarien. Les cellules en gélatine semblent convenir pour obtenir la reproduction de l'acarien dans des conditions de laboratoire et, en raison de leur transparence, pour faire des observations sur le comportement de l'acarien à l'intérieur de la cellule.

\section{Varroa jacobsoni / reproduction in vitro}

\section{Zusammenfassung - Eine Technik zur} Reproduktion von Varroa jacobsoni Oud unter Laborbedingungen. Frühere Untersuchungen zeigten, daß die Aufzuchtbedingungen eine wichtige Rolle für die Reproduktion der parasitischen Milbe Varroa jacobsoni spielen. Bisher wurden Zellen aus verschiedenen Materialien getestet, um ihre Eignung für die Haltung der Milbe unter Laborbedingungen zu ermitteln. Die Anzahl fertiler Weibchen war unter diesen Bedingungen immer sehr viel kleiner als im Bienenvolk. Hier wurden Versuche mit Zellen aus Gelatine durchgeführt. Varroa Weibchen wurden 0-15 Stunden nach der Verdecklung aus der Brutzelle genommen und auf Larven gleichen Alters in die künstlichen
Zellen transferiert. Die Haltung erfolgte im Brutschrank bei $34,5^{\circ} \mathrm{C}$ und $75 \%$ Luftfeuchtigkeit. Nach 12 Tagen wurden die Zellen geöffnet und unter einem Präpariermikroskop untersucht. Die Mortalität, Fertilität und Nachkommenzahl der Varroa Weibchen wurde bestimmt. Künstliche Bienenwachszellen und Gelatinezellen mit unterschiedlichen Durchmessern wurden verglichen. In den Gelatinezellen war der Anteil fertiler Varroa Weibchen viel höher als in Wachszellen mit gleichem Durchmesser (Tabelle I), in $6,0 \mathrm{~mm}$ Zellen aus Gelatine wurde ein Anteil von $71 \%$ erreicht (Tabelle II). Bei beiden Materialen war der Prozentsatz in den kleineren Zellen höher (Tabellen I, II). In allen Versuchen betrug der durchschnittliche Anteil von sich vermehrenden Weibchen $62 \%$; in 6,0 mm Gelatinezellen betrug die Anzahl der Nachkommen 3,5 (Tabelle III). Diese Ergebnisse bestätigen die Bedeutung der Aufzuchtbedingungen für die Reproduktion der Milbe. Gelatinzellen scheinen geeignet für eine Reproduktion der Milbe unter Laborbedingungen zu sein. Durch ihre Transparenz ist es außerdem möglich, Beobachtungen über das Verhalten der Milbe innerhalb von verdeckelten Zellen anzustellen.

\section{Varroa jacobsoni/ in vitro Reproduktion}

\section{REFERENCES}

Abbas N D, Engels W (1989) Rearing of Varroa in artificial cells on drones. In: Present Status of Varroatosis in Europe and Progress in the Varroa Mite Control. Proc Meet EC Experts Group, Udine (Cavalloro $\mathrm{R}$ ed) CEC, Luxembourg, 223-228

Accorti M, Nannelli R (1988) Osservazioni particolari sull'allevamento di Varroa jacobsoni Oud su stadi preimmaginali di Ape in ambiente controllato. In: Atti XV Congresso Nazionale Italiano di Entomologia, L'Aquila, Italy, 481-488

Avdeeva OI (1978) Life cycle of the Varroa mite in laboratory conditions. Pchelovodstvo 10, 16-17 (in Russian)

Avdeeva O I (1979) The biology of nutrition of the Varroa mite under laboratory conditions. Pchelovodstvo 8 , $18-19$ (in Russian) 
Beetsma J, Zonnenveld K (1992) Observations on the initiation and stimulation of oviposition of the Varroa mite. Exp Appl Acarol 16, 303-312

Chiesa F, Milani N (1988) Some preliminary observations on the behaviour of Varroa jacobsoni Oud on its natural host under laboratory conditions. In: European Research on Varroatosis Control. Proc Meet EC Experts Group, Hamburg (Cavalloro R ed) Balkema, Rotterdam, The Netherlands, 113-124

Chiesa F, Milani N, D'Agaro M (1989) Observations of the reproductive behaviour of Varroa jacobsoni Oud: techniques and preliminary results. In: Present Status of Varroatosis in Europe and Progress in the Varroa Mite Control. Proc Meet EC Experts' Group, Udine (R Cavalloro, ed) CEC, Luxembourg, 213-222

Donzé G (1989) Untersuchungen zur Fortpflanzung der Varroa. Schweiz Bienenztg 112, 72-77
Issa M R, Gonçalves S (1985) La technique de l'induction de la ponte chez l'acarien Varroa jacobsoni en conditions de laboratoire. In: Proc XXXth Int Congr Apic, Nagoya, Apimondia, Bucharest, Romania, 157158

Fisher R A (1970) Statistical methods for research workers. XIV ed, Oliver and Boyd, Edinburgh, UK

Milani N, Chiesa $F$ (1990) Some stimuli inducing oviposition in Varroa jacobsoni Oud. In: Proc Int Symp on Recent Research on Bee Pathology, Gent (W Ritter, ed) Apimondia, Bucharest, Romania, 27-33

Sakai T, Takeuchi K, Hara A (1979) Studies on the life history of a haneybee mite, Varroa jacobsoni Oudemans, in laboratory rearing. Bull Fac Agric Tamagawa Univ 19, 95-103 (in Japanese)

Schulz A E (1984) Reproduktion und Populationsentwicklung der parasitischen Milbe Varroa jacobsoni Oud in Abhängigkeit vom Brutzyklus ihres Wirtes Apis mellifera L. (1. Teil) Apidologie 15, 401-420 